\title{
Law \& Orator: Depicting Cicero through Modern Mystery Fiction
}

\section{Introduction and Methodology}

Cicero's work as an advocate in the Roman law courts has been the topic of fictional narratives for centuries, ${ }^{1}$ but to those unfamiliar with Cicero's representation in modern popular culture, it may still be surprising that many recent depictions of Cicero's forensic speeches have taken the form of mystery stories. ${ }^{2}$ The mystery narratives that feature Cicero as a character allow authors and creators to meditate on well-trodden questions of Cicero's controversial morality and the morality of rhetoric itself. ${ }^{3}$ As a result of these mystery narratives' influence, certain tropes from the detective fiction genre have made their way into other works that depict Cicero's life within more traditional genres such as historical biopic and epic. This chapter demonstrates that a more intimate understanding of mystery story conventions enables us to develop a correspondingly richer understanding of Cicero's reception.

In this analysis, I consider not only modern novels, but also an array of contemporary media including visual and auditory materials, all of which depict Cicero acting as a legal advocate or as an orator more broadly. ${ }^{4} \mathrm{My}$ argument will proceed chronologically through Cicero's life, highlighting the tropes most com-

1 Or rather for millennia, if one considers the work of the early declamatory tradition to be fiction. Cf. Roller 1997, Wright 2001 and Keeline 2018, explored later in this paper, as well as La Bua 2019.

2 This paper mainly considers fictions written in English, with the exception of the Italian novel Il diritto dei lupi (2021).

3 For Cicero's own discussion on the morality of rhetoric, see De oratore (explored in Wisse 2002 and Fantham 2004). See also Quintilian's meditations on Cicero, oratory, and the vir bonus (explored in Brandenburg 1948; Gowing 2013, 244-250; and van der Blom, p. 247-266 in this volume). For an academic attempt at the to grasp Cicero's occasionally slippery morality, see Remer 2017.

4 With one exception, I will also be "confining myself to works in the English language", after the excellent example of Fotheringham 2013, 350. Fortunately, English language "works in which Cicero is the central character", are not quite so unusual as they were at the time of Fotheringham's study: notable new arrivals include the audio-dramas Llewellyn 2017, 2018a, 2019, and 2021, as well as the stage play Poulton 2017. Fotheringham also omits two older novels starring Cicero: Wagner/Wagner 1961, and Caldwell 1965.

Ә OpenAccess. (C) 2022 Kathryn H. Stutz, published by De Gruyter. (cc) BY This work is licensed under the Creative Commons Attribution 4.0 International License. https://doi.org/10.1515/9783110748703-013 
mon to each phase of his career, in order to show the moral arc imposed upon Cicero's personal, professional, and political choices. Because these phases are each tied to specific pieces of Cicero's oratory, an understanding of the extant adaptations for each Ciceronian speech is vital; a pair of tables illustrating which modern fiction sources feature each speech can be found in Table 1 ("Modern Portrayals of Cicero's Oratory by Date of Ciceronian Speech") and Table 2 ("Modern Portrayals of Cicero's Oratory by Date of Modern Media Publication"). By examining the choices that artists and authors make when portraying Cicero as an orator, both in terms of adapting ancient source material ${ }^{5}$ and contrasting specific characters as moral agents within a narrative framework, this study asserts that murder mystery genre tropes have played an important role in providing different answers to the contentious question: Was Cicero the orator morally just? As Ellen O'Gorman asserts in her examination of ancient Roman mystery fiction, "the comparison of history and detective fiction can put the nature of historical writing under considerable scrutiny". ${ }^{6}$ Thus, this paper argues, fiction (or, what O'Gorman calls “'fictive' knowledge”) can illuminate the darker corners of the historiographical tradition, forcing us to examine our assumptions about truth, justice, and morality. ${ }^{7}$

\section{Young Cicero: The Pro Roscio Amerino}

Some of the historical court cases in which Cicero served as an advocate lend themselves better to standard mystery narratives than do others. A key example is one of Cicero's very first cases, the defense of Sextus Roscius of Ameria against the charge of parricide, known as the Pro Roscio Amerino. ${ }^{8}$ In this apparently paradoxical case, young Roscius faced charges before the quaestio perpetua de

\footnotetext{
5 For the value of asking questions of historicity, authenticity, and accuracy when evaluating receptions of the ancient world, cf. Fotheringham 2013, 355, who further cites Winkler 2004, 16-24, and Wyke 1997, 13.

6 O'Gorman 1999, 19.

7 The forensic courtroom has, at times, been a questionable place for the display of morally upright brilliance; for more discussion, see van der Blom, p. 247-266 in this volume, which characterizes Quintilian as offering "the senate and the contio as the venues in which a good orator's glory will shine more brightly” than in the forensic courtroom (256). In Cicero's day, forensic oratory could form the path toward a productive political career, but not necessarily toward a spotless reputation.

8 Cf. Grant 1975, 23-110, for an English translation of the Pro Roscio specifically cited by one modern creator of Cicero fiction as a significant source of inspiration and several direct quotes (Llewellyn 2018b).
} 
sicariis for the death of his father, Roscius the Elder, despite the fact that the name of this elder Roscius had been added to the proscription lists of Lucius Cornelius Sulla. Though the importance of uniquely Roman cultural features such as the Sullan proscriptions and the larger context of the war between Marius and Sulla can make this criminal case somewhat difficult to present to modern audiences unfamiliar with Roman history, ${ }^{9}$ the traditional elements of the murder mystery that surround the death of Roscius the Elder do lend themselves plausibly well to adaptation. According to Timothy W. Boyd and Carolyn Higbie (both scholars of Greek antiquity who turned their classical scholarship toward better understanding mysery literature), for any given action to be deemed a crime and therefore "act as the motivating power" in a historical detective novel, the crime "must be linked with appropriate legal, or at least retributive, structures" both within the novel's historical context and within the imaginative world of the reader. ${ }^{10}$ The Roman court system, in which Cicero acts as an advocate, serves as a legal structure in which the crime of parricide can be prosecuted, providing a relatively familiar setting even for audiences new to the world of ancient Rome. Assuming - at least for now - that a fictional Cicero is aligned with the side of truth and justice, Cicero's forensic oratory ought to ensure that justice will be found within the Roman courtroom, but in order for Cicero the orator to lay out the facts for the court, these facts must first be uncovered during the course of an investigation. The question of who will serve as an investigator can be answered in one of two different ways, depending on how the Pro Roscio case has been fictionalized: either Cicero could hire someone else to serve as a sort of private detective, or Cicero could undertake the investigation himself. Neither of these paths necessarily demand a more or less moral Cicero by our standards, but the implications are very different from a narrative standpoint. A young Cicero digging through archives of proscription lists, questioning witnesses, and placing himself physically in danger in order to serve his client, for example, makes for a sort of Sherlockian detective-hero, searching for the truth amidst the chaos of republican Rome. We see this sort of heroic Cicero in a BBC docudrama titled Murder in Rome, ${ }^{11}$ as well as in the first episode of the audio-

9 Butler 2002, 14-23 examines the logical issues with these criminal charges and how Cicero navigates them.

10 Boyd/Higbie 1997, 20.

11 Swash 2005. Cf. Fotheringham 2013, 360 - 361: "Cicero is pressurized into defending Roscius at the last minute, and when the trial begins he still knows next to nothing about the case. This turns the trajectory of the episode into that of a murder-mystery. At one point the young orator is shown consulting the proscription lists himself - apparently the first person to do so - at night, by torchlight, searching for "clues". The unexpected appearance of a further witness from Ame- 
drama Cicero, written by David Llewellyn. ${ }^{12}$ About his process writing this audiodrama, Llewellyn wrote:

Cicero is interesting because he lived to a decent age, and was writing down his thoughts for much of his adult life. Like anyone, his views and his values changed with time. [Writing the audio-drama] was a case of trying to work out who he was in his twenties, while allowing for the fact that he [would] be a very different person by the end of the Republic. ${ }^{13}$

Specifically, Llewellyn identified this later Cicero as a politician willing to enact violence - in this case, against the members of the Catilinarian conspiracy whereas Llewellyn's “young Cicero” of the Roscius trial displays a moral position cleanly opposed to violence in all its forms, and his passionate methods of investigation and forensic presentation make him a compelling protagonist. ${ }^{14}$ Because of his youth, this Cicero still has hope that there can one day be peace in Rome through the balance of justice and law; similarly, in the recent Italian novel $\mathrm{Il} \mathrm{di-}$ ritto dei lupi - also set during the Pro Roscio trial - a young Cicero meets with powerful political forces who attempt to draw him into corruption, and when he refuses, they name him "Un idealista" in contrast to the gritty corruption of the Roman republic. ${ }^{15}$ Llewellyn similarly includes a scene of confrontation with the corrupt higher powers controlling Rome, in which his morally upright Cicero turns away from bribery; on the whole, however, Llewellyn achieves his own hopeful characterization of his young protagonist largely through his careful inclusion of Cicero's own words from the written Pro Roscio Amerino. In the

ria also contributes to the detection aspect of the plot. The choice of the murder-mystery format is interesting in the light of the tremendous success of historical murder-mystery novels in recent decades" [italics in original]. Fotheringham's comprehensive treatment of the BBC docudrama requires little additional scholarly comment within the present study, but serves as an excellent comparanda to the audio-drama adaption of the Pro Roscio (Llewellyn 2017).

12 Llewellyn 2017; cf. also Llewellyn 2018a.

13 Llewellyn 2018b.

14 Much like the protagonist Cicero in BBC's Murder in Rome (Swash 2005), about which Fotheringham notes, "our sympathies are further engaged by the fact that Cicero is the detective/protagonist, the seeker after truth. The Roscius episode can be easily played in Cicero's favour, and here he is presented as both a young man, played by a good-looking actor, and an underdog, easily engaging the audience's sympathies" (2013, 361). Although Llewellyn's audio-drama does not have a visual component, and thus lacks the ability to show whether its protagonist is "good looking”, Llewellyn's script for Episode I plays up the tropes of Cicero's youth and his position as an underdog (Llewellyn 2017), while the scripts for Episodes II-VI incorporate this Cicero into a network of romantic subplots: a rare type of narrative for Cicero, especially within works featuring Cicero as a sympathetic protagonist (Llewellyn 2018a).

15 De Bellis/Fiorillo 2021. 
first episode of the audio-drama, the fictional Cicero addresses the courtroom with a speech closely adapted from the conclusion of the extant Pro Roscio.

Judges, it is up to you to stamp out this cruelty from our midst. We must suffer it no more. That cruelty - it has familiarized us with evil in all its forms, stifling pity in the hearts of merciful people. Hour after hour we hear of these appalling deeds, and this repetition of horrors drains even the gentlest natures of their humanity. Well, today let's draw a line. Today, let us say, enough. ${ }^{16}$

This oratory borrows heavily from the last section (Cic. S. Rosc. 154) of Pro Roscio Amerino, with only minor rhetorical flourishes having been added; entire phrases of the English translation remain intact in the Cicero audio-drama. ${ }^{17}$

By contrast, in Roman Blood, the first of Steven Saylor's Roma Sub Rosa mystery novels, Cicero plays the role of a patron and lawyer - but not detective within the same Pro Roscio Amerino narrative. ${ }^{18}$ Instead, Cicero hires the fictive detective "Gordianus the Finder" to investigate the Roscius case. With this Gordianus character presented not only as the narrator but also as the narratological protagonist and moral hero, Cicero is free to be portrayed as morally corrupt, concerned only with defending his client at all costs, regardless of the truth. Though Cicero here remains a major character - unlike the more marginal role that he receives in other media, such as HBO's Rome - the contrast Saylor draws between Gordianus and Cicero casts Cicero in a negative light as soon as Cicero is introduced. As Gordianus himself suggests near the novel's beginning, Roman advocates and orators “don't necessarily have to believe in a point to argue for it" ${ }^{19}$ a perspective that the historical Cicero himself appeared to voice later in his life. ${ }^{20}$ While Saylor's Gordianus searches exhaustively for the truth, no matter how unpleasant, Saylor's Cicero has no use nor time "for anything that distracts from the simple, closed circle of logic" that comprises Sextus Roscius' defense, irrespective of the consequences for the safety of the Roman state. ${ }^{21}$ Perhaps the clearest image of the contrast between Llewellyn's heroic

16 Llewellyn 2017.

17 Llewellyn's assertion that he used Grant's 1975 translation of the Latin (Llewellyn 2018b) can be corroborated by the direct borrowing of phrases such as "it is up to you to stamp out this cruelty from our midst", "evil in all its forms", "appalling deed[s]", and the "repetition of horrors" that "drains even the gentlest natures of [...] humanity".

18 Saylor 1991.

19 Saylor 1991, 49.

20 Cic. Clu. 139, explored further in the following section 3. Mid-Career Cicero: Corruption Cases and Concealing Cluentius.

21 Saylor 1991, 250. 
young Cicero and Saylor's anti-heroic one is the appearance within Saylor's narrative of the same passage of the Pro Roscio Amerino that Llewellyn used: Cicero is made to say the same familiar sentiments, as he exhorts the judges to "suffer this wickedness no longer to stalk abroad in the land", saying that "it has stifled all pity in a people once known as the most merciful on earth", and "even the kindest and gentlest among us may lose all semblance of human compassion", 22 but in Saylor's text, these phrases lack the moving sentiment that Llewellyn's voice actor Samuel Barnett provides, since, in Saylor, they are heard by Gordianus only as a distant echo from within a public Roman toilet. ${ }^{23}$ The grimy setting mirrors the changed meaning of Cicero's words in this context: in Saylor's novel, Roscius is guilty, and Cicero's speech in his defense is an inherently immoral act committed in support of a murderer and abuser. A far cry from the glory of Llewellyn's young Cicero heard orating from the center of the forum - when placed side by side, Saylor's and Llewellyn's disparate interpretations of the same historical event constitute mutually exclusive claims to O'Gorman's “fictive knowledge". ${ }^{24}$ In Saylor's novel, evil is endemic to Rome, and Cicero embodies that evil, while in Llewellyn's city, young Cicero's hope in humanity is the only thing capable of standing against the corruption of the state, itself not inherently evil, but instead simply buried underneath an accumulation of many overlapping patterns of violence, just as the historical Cicero claimed.

\section{Mid-Career Cicero: Corruption Cases and Concealing Cluentius}

Saylor's Cicero lacks not only a heroic narrative role and aesthetic, but also a heroic morality, at least from a modern mystery fiction perspective. ${ }^{25}$ In truth, most systems of modern legal ethics instruct defense attorneys to prioritize serving their clients, but a fictional Cicero is never only a lawyer: he is also a political actor, whose ideas of truth, justice, and violence have broader ramifications. For this reason, we see a disproportionately high representation of Cicero's mid-ca-

22 Saylor 1991, 360.

23 Saylor 1991, 357.

24 O'Gorman 1999, 19.

25 Cf. Fotheringham 2013, 358, who adds that "Saylor has admitted in interviews that he started off with the idea of making Cicero the detective and protagonist, but as he researched the character he found him more and more difficult to view as either a seeker after truth or a hero. The invented character of Gordianus, who is both, presents Saylor's negative view of Cicero to the reader as first-person narrator of the novels". 
reer corruption cases in non-mystery fiction, compared to detective-style works. Biopic and epic stories such as Taylor Caldwell's A Pillar of Iron, ${ }^{26}$ the Cicero Trilogy of Robert Harris, ${ }^{27}$ and Mike Poulton's stage adaption of the Harris trilogy, ${ }^{28}$ often use the morally upright In Verrem and the more problematic Pro Fonteio to flesh out the complexity of their fictional Cicero's morality. A truly broad depiction of Cicero's life, like those offered by Harris and Caldwell, may choose to omit Cicero's minor cases, especially non-mysterious legal matters like property disputes. ${ }^{29}$ In Verrem and Pro Fonteio, however, accomplish an important political balancing act: while In Verrem becomes a rich source for showing Cicero as a new politician stamping down government corruption, Pro Fonteio remains a damning piece of evidence for Cicero's willingness to defend corruption if politically expedient. A mystery lens helps can reveal the narrative impact of this tension: though traditional tropes that characterize the heroic detective figure are largely absent from depictions of Cicero orating the Pro Fonteio, adaptations of the In Verrem, in contrast, show vivid images of Cicero's detective processes, from Harris' Cicero with his “toga hoisted around his knees, his fine red shoes in one hand, his warrant in the other, picking his way daintily across a muddy field in the pouring rain to take evidence from a farmer at his plow"30 to the triumphant verse, "trust me: Cicero wrote it all down" in "Song for Cleomenes", an indie folk song about In Verrem. ${ }^{31}$ This is Cicero at his most heroic and, simultaneously, at his most detail-oriented, collecting the facts for his prosecution of Verres, a clear villain.

In classic detective literature, the quest that elevates the protagonist to hero status is the act of searching for the truth, but applying this mystery-quest to a figure like Cicero can become awkward in circumstances where Cicero was known to prioritize the acquittal of his clients above empirical truth. While discussing the importance of truth-value to Roman juries, Andrew Riggsby cites a well-known quote of Quintilian's concerning Cicero: regarding Cicero's defense of Cluentius, Quintilian says, "nor did Cicero himself lose his sight [of the truth], when he boasted that he had covered the jurors in shadow in Cluentius'

26 Caldwell 1965.

27 Harris 2006; 2009; and 2015. For In Verrem and Pro Fonteio specifically, see Harris 2006. 28 Poulton 2017, 17-20. The treatment of In Verrem in Poulton's script is brief, and the Pro Fonteio is regrettably omitted, but this is unsurprising in a stage-play script attempting to summarize Cicero's long career into two nights at the theatre.

29 To my knowledge, no modern fictional treatments yet exist for the Pro Quinctio or the Pro Tullio, for example.

30 Harris 2006, 219.

31 Darnielle 1994. 
case" (nec Cicero, cum se tenebras offudisse iudicibus in causa Cluenti gloriatus est, nihil ipse vidit). ${ }^{32}$ As Riggsby explains, this statement suggests that not only did Cicero prioritize the presentation of a strong defense case over the dissemination of true facts, but he did so fully aware of the ethical implications of his choice, in the context of a Roman courtroom where "guilt and innocence [did] matter to the jury, if not to the advocate personally". ${ }^{33}$ While, according to Quintilian, Cicero claimed afterward to have deceived these jurors with rhetoric, in the written Pro Cluentio of our tradition, Cicero asserts - in what could be construed as an act of meta-deception - that "a court of law is the abode of truth" (locum in iudiciis veritati). ${ }^{34}$

Quintilian's quotation suggests a broader story; in fact, the Pro Cluentio has been the foundation for at least one modern courtroom-drama style mystery novel, in which the facts of the case unfold during a series of unofficial depositions that Cicero conducts with his new client, Cluentius, who has been accused of poisoning his stepfather. This depiction of the Pro Cluentio, in the 1961 novel The Gift of Rome,$^{35}$ manages to present a morally grounded Cicero - despite the falseness of his legal argument - by incorporating features of Cicero's broader political life, in the style of biopic media like the Cicero Trilogy of Robert Harris. During Cicero's forensic speech on behalf of Cluentius, the narration reports that:

[Cicero] spoke of the law of Rome. He spoke of order imposed by the minds of men upon the disorders of their own existence; an order forever the same in the shifting tides. Behind all flux, one permanence: the gift of Rome; a structure built out of men's many answers to the question: what is justice? ${ }^{36}$

These same sentiments are repeated in private to Cicero's confidant, Atticus; here is a Cicero who truly believes in an idealistic version of the broader picture. In contrast to Saylor's Cicero, who defends his morally bankrupt client without regard to the consequences for Rome, the Wagners' Cicero defends his guilty client precisely because of the civic consequences. His legal advocacy is a part of his own broader project to create social, political, and moral justice, to build an or-

32 Quint. 2.17.20 - 21, transl. Riggsby 1997, 242.

33 Riggsby 1997, $250-251$.

34 Cic. Cluent. 202, transl. Grant 1975. See also the elegant discussion of truth within Quintilian's treatment of the Pro Cluentio case in Steel, p. 243 in this volume, and compare the significance of truth-finding for Montesquieu's reading of Cicero, in Moraes Santos, p. 341-367.

35 Wagner/Wagner 1961.

36 Wagner/Wagner 1961, 53. 
derly Rome where equites like himself and Cluentius may thrive; this fictive Cicero is deserving of Quintilian's praise of a man possessing upright voluntas. ${ }^{37}$ Though Cicero's individual actions may lack a perfect morality, his generally good intentions nevertheless redeem him. The Wagners, in The Gift of Rome, even reference the same Quintilian quote about Cicero's deception in the Pro Cluentio, saying that Cicero "had mocked at verdicts, overthrown rulings, and thrown dust in the eyes of jurors", ${ }^{38}$ and yet this does not make their Cicero a villain, because "in the last depths of his deep heart his love of the law of Rome lay hard and perfect, never to be touched". ${ }^{39}$ Whether or not the Wagners' Cicero has a realistic vision for Rome, or even a plan that would benefit the majority of Rome's citizens, this Cicero's deeply held convictions allow him to fill the role of the narrative hero.

\section{Mature Cicero: Vis and Violence}

As Cicero matured and Rome drew closer to the end of its time as a republic, more of Cicero's court cases dealt with the intricacies of violence. As Aislinn Melchior asserts, many of the historical Cicero's speeches served as "a call for action from his audience" that "exploit the full emotionalism of vividly portrayed violence". ${ }^{40}$ As such, it is not surprising that some of Cicero's later cases - which feature more often in modern mystery narratives - are typically violent: the Pro Milone, for example, so popular with early imperial writers and practitioners of rhetoric, ${ }^{41}$ has appeared in mystery author Kenneth Benton's Death on the Appian Way, ${ }^{42}$ as well as within a Steven Saylor serial with a similar title, A Murder on the Appian Way. ${ }^{43}$ "Because violence is so powerful", Melchior argues, "the way that one portrays violence is also imbued with power". ${ }^{44}$ This potential for power and violence through speech can make Cicero's motivations appear sinister when his morality does not align with our own, and sinister motives can provide an opportunity for certain authors to construct amoral or even villainous portrayals of Cicero. The importance of violence within Cicero's legacy

37 See Stoner, p. $86-87$ in this volume.

38 Wagner/Wagner 1961, 206 [italics mine].

39 Wagner/Wagner 1961, 206.

40 Melchior 2004, 12.

41 See van der Blom, p. 247-266 in this volume.

42 Benton 1974.

43 Saylor 1996.

44 Melchior 2004, 3. 
likely also explains the predominance of modern depictions of the Catilinarian conspiracy: a total of six separate works can be found under the "In Catilinam [63 BCE]" stemma in Table 1. As can be seen in the previous phases of Cicero's career, even a contentious case like Cicero's pursuit of Catiline and execution of the co-conspirators can be thrown in either a positive or a negative light. In his second novel, Lustrum, Robert Harris "to some extent protects his Cicero from criticism" by describing politics in Rome as a "dirty business" with which Cicero, as a politician, must engage by necessity. ${ }^{45}$ Poulton, with the sympathetic example of Harris as his source material, begins his stage play with Cicero investigating a violent murder, ${ }^{46}$ playing up the mystery tropes to paint Cicero as a detective seeking the truth first and foremost. In contrast, David Llewellyn's first look at the Catilinarian conspiracy takes a harsher view, focusing on Cicero's execution of the conspirators without a trial. In the crossover episode "Tartarus", of Doctor Who - The Monthly Adventures, Cicero, here given a brief co-starring role in this on-going science fiction audio-drama based on the famed BBC TV show Doctor Who, confronts the vengeful ghosts (lemures) of those he has ordered to be killed while he was consul. ${ }^{47}$ Even so, Llewellyn's Cicero is redeemed again by his voluntas - politics is a "dirty business" and the fact that Cicero feels guilt over his actions is enough to redeem him and bring him back to the position of co-protagonist by the episode's end. As the Doctor says to Cicero, "I've met beings across the universe who've spent their entire lives being cruel. And that is not how you'll be remembered" which, judging from the still-heroic Cicero of 59 BCE portrayed in the sequel series Cicero: The Crossroads, appears to be true. ${ }^{48}$ Unsurprisingly, Steven Saylor uses his own interpretation of In Catilinam, the novel Catilina's Riddle ${ }^{49}$ to further criticize the social violence of Cicero's self-serving politics in contrast both with the protagonist-detective Gordianus as well as Saylor's seductive Catiline. Yet even certain texts that retain a sympathy for Cicero despite his role as executioner, such as The Catilinarian Conspiracy by John Maddox Roberts, ${ }^{50}$ reveal an assumption that some part of the Roman republic perished with Catiline. The summer of 63 BCE was "the last summer of the old Republic", Roberts' fictional narrator opines: "it died in the fall" - the fall of Cicero's consulship, that is. ${ }^{51}$ Such statements echo the sentiments

45 Fotheringham 2013, 369; Harris 2009, 475.

46 Poulton 2017.

47 Llewellyn 2019.

48 Llewellyn 2019, Llewellyn 2021.

49 Saylor 1993.

50 Roberts 1991.

51 Roberts 1991, 12. 
of scholars like Harriet Flower, who asserts that "an argument can be made that it was Cicero who was responsible for a dangerous undermining of republican values when he declared an emergency, executed Roman citizens and even a fellow magistrate without a trial, and raised the specter of civil war and arson in the city" thereby signalling an end to traditional republican forms of government. ${ }^{52}$

\section{The End of Cicero: The Philippicae}

The most memorable episode of brutal violence in Cicero's life, however, is a murder for which no murderer ever stood trial: Cicero's own proscription and slaughter in 43 BCE. Unsurprisingly, many modern historical fiction narratives narrow in on the iconic end of Cicero's life. At first glance, there seems to be very little mystery to Cicero's death. We know precisely why he was killed; the motive is clear, and the basic facts of his proscription by the second triumvirate are historically very well attested. There is a broader question, however, which many of these epic narratives attempt to answer: while conflating Cicero's death with the end of the de facto rule of elected officials in Rome, and therefore the end of the republican form of government, we often ask, why did the Roman republic die? By whom was it killed? History allows a nuanced answer to this question: the republic was crumbling already: it had been broken since before Cicero was born, and many people played a role in dealing the death blows. History does not have one single explanation for this mystery - it has many. As Harriet Flower argues, the idea of the "Roman republic" died many deaths, changing radically even over the course of just Cicero's own lifetime. ${ }^{53}$ This lack of political continuity, however, rarely makes its way into fiction, a genre where the lens of the protagonist's journey takes preeminence over other, more sociological narratives. Robins Winks records a "saying among historians" that "one will never know precisely why the ship of state sank because there are too many eye witnesses" whereas "detective fiction in its lonely voice that insists upon individual responsibility, strips the eyewitnesses down to two: the author and the reader". ${ }^{4}$ By refocusing on the ongoing detective narrative of Cicero's life, we find that some of these smaller questions of individual responsibility have been left unan-

52 Flower 2010, 146.

53 Flower 2010, cf. esp. “The 'Last Generation' of the Roman Republic”, 161-162.

54 Winks 1980, 10. 
swered. How precisely did Cicero die? What events led to his proscription? Who's really to blame? ${ }^{55}$

To answer these questions, we must untangle the complicated web of historical accounts and literary depictions that have preserved, in words, Cicero's last days. In his examination of early narratives of Cicero's death, Matthew Roller observes that the sequence of events is not, in fact, commonly agreed upon, because Cicero's death-story does not come to us through "a purely textual, literary transmission" but instead, the oral exercises known as declamationes - fictitious legal defenses practiced in the schools of rhetoric - codified the tradition of Cicero's death. Roller asserts that it is "the logic of these exercises, and of declamation as a whole, that largely defines the range and character of the variations in the death-of-Cicero tradition". ${ }^{56}$ This path of scholarship has led to the perception, as articulated (to take one example from within the realm of scholarship on Cicero's reception) by Eran Almagor, who finds two "strands" in Roller's model of Imperial reception regarding Cicero's death, and asserts that "only one strand in the tradition of Cicero's death is committed to the relation of facts" (that is, historiography as practiced by writers like Livy) whereas "the other [strand] comes from the field of invention" - that is, declamation, or the "presentation of deliberative and legal dilemmas, in which imagination and fiction are given a free rein". ${ }^{57}$ Were this the case, it should be simple enough to select one strand (i.e., the early historical sources - Livy and the Latin historians quoted directly in sources like the Suasoriae and Controversiae of the Elder Seneca) and discard the other strand; the past two decades of scholarship, however, have revealed a rather more tangled narrative knot.

In contrast to Almagor, Andrew Wright contends that the entire "historical record has been contaminated by a fiction generated by the practice of declamation", ${ }^{58}$ and more recently, Keeline has argued that, from the time of the early empire, the historical "picture of Cicero, and especially of his death, is thus painted with declamatory colores". ${ }^{59}$ Because of this fictionalizing influence of declamation on the story of Cicero's death, we are left with a network of death

55 For an answer to this last question as it pertains to the rhetorical maneuvering which allowed Augustus to displace his own responsibility for Cicero's death onto Marc Antony, see Keeline 2020.

56 Roller 1997, 110.

57 Almagor 2015, 62.

58 Wright 2001, 437.

59 Keeline 2018, 146. For another example of the type of declamatory fiction that colored the historical tradition of Cicero's death, see Keeline, p. 119-141 in this volume, especially the discussion of Lucius Aelius Lamia beginning on page 122. 
narratives that are concerned not with historical fact but with rhetorical strategies of persuasion in the same way that the historical Cicero's speeches often prioritized victory over truth. Cicero and the texts about him have become one, united by their unique blend of fiction and falsehood. Yet this must not be understood as a lack of narrative concern for justice - as we have seen in these historical mystery works, Cicero's perspective and morality may change, but his concern for (and, ultimately, his conflation with) the Roman republic stays the same, whether he serves as its murderer or as its fellow victim.

Right or wrong, Cicero was convinced that he knew the precise origin of the evils plaguing the republic in 43 BCE: men who disrespected the authority of the senate by supporting Caesar's indefinite dictatorship, men like Marc Antony. Even media that portray Cicero as somewhat peripheral to the power-struggle of the late Republic, such as HBO's television show Rome, often make use of Cicero solely as a vessel for the critique of the power-grabbing Antony. In the third episode of the second season of Rome, titled "These Being the Words of Marcus Tullius Cicero”, a messenger reads aloud Cicero's climactic invective, a pastiche of second Philippic tropes.

\footnotetext{
When I was a young man, I defended our state. As an old man, I shall not abandon it. I give sincere thanks to Marc Antony, who has generously presented me with the most promising theme imaginable. I address you directly, Antony. Please listen, as if you were sober and intelligent, and not a drink-sodden, sex-addled wreck. You are certainly not without accomplishments. It is a rare man who can boast of becoming a bankrupt before even coming of age. You have brought upon us war, pestilence, and destruction. You are Rome's Helen of Troy. But then, a woman's role has always suited you best. ${ }^{60}$
}

While not as faithful a copy as the versions of other Cicero orations that appear in novels like those of Saylor, Harris and the Wagners, or in the audio-dramas of Llewellyn, traces of the Latin remain even in this televised format: from the opening line, "I defended the republic as a young man, I will not abandon it now that I am old" (defendi rem publicam adulescens, non deseram senex), ${ }^{61}$ and the brazen exhortation, "for a moment think of the business like a sober man" (attende enim paulisper cogitationemque sobrii hominis punctum temporis suscipe), ${ }^{62}$ to the references to Antony's checkered past, "do you recollect that, while you were still clad in the praetexta, you became a bankrupt?" (tenesne me-

60 Buck 2007, 45:20.

61 Cic. Phil. 2.118, transl. Yonge 1903.

62 Cic. Phil. 2.31, transl. Yonge 1903. 
moria praetextatum te decoxisse?), ${ }^{63}$ and, of course, the final epic simile, "as Helen was to the Trojans, so has that man been to this republic: the cause of war, the cause of mischief, the cause of ruin" (ut Helena Troianis, sic iste huic rei publicae belli causa, causa pestis atque exiti fuit). ${ }^{64}$ Although scrambled, exaggerated, and placed within a modern matrix, these fragments of authentic Ciceronian oratory provide a compelling motive for Antony's impassioned desire for the death of Cicero. Within the episode, Antony's reaction to this speech is sudden and violent: he very literally kills the messenger who hesitantly recites these words. Here, Cicero is used as a contrast to Antony in much the same way as he is used in Saylor's novels as a contrast to Gordianus, though the moral implications have reversed direction. Set beside Gordianus, Cicero makes Saylor's protagonist appear heroic, while in HBO's Rome, Cicero makes Antony's slow moral decent take on rapid speed. Yet this does not make HBO's Cicero a hero - as Lynn Fotheringham observes, Cicero "shows some backbone in standing up to Antony, and he dies bravely" yet "on the whole, he comes across as faintly ridiculous". ${ }^{65}$ This televised Cicero is a symbol of the problems with the Roman republic: he is hapless, out of touch with the violent, physical reality lived by the Roman people and by military men like Antony.

Other death-of-Cicero stories from diverse modern genres similarly frame Cicero's invective in the Philippics as the inciting incident leading ultimately to his proscription. Like an unsympathetic murder victim in a classic mystery novel, guilty of numerous offenses for which any number of personal enemies might want him dead, Cicero is shown to be flawed in much the same way that Robin Winks describes the failings of the mystery genre itself:

63 Cic. Phil. 2.44, transl. Yonge 1903.

64 Cic. Phil. 2.55, transl. Yonge 1903.

65 Fotheringham 2013, 354. Fotheringham largely locates this ridiculousness in the physicality of the actor, David Bamber, whom she calls, "not particularly attractive", "far too young for the part, historically speaking”, and "lacking Cicero's proper gravitas”. While these criticisms are not untrue, the focus on Bamber as an actor elides the fact that, throughout the two seasons of the show Rome, Antony's interactions with Cicero are played as forms of sexualized violence, a pattern that hits its peak in the eighth episode of the first season, "Caesarion". After most of the senators have left the senate hall for the day, Antony tenderly asks Cicero to place his hands in Antony's, at which point Antony grabs Cicero by the wrists, forces him to his knees, and declares "If I ever again hear your name connected with murmurs of treachery, I will cut off these soft, pink hands, and nail them to the Senate door", after which he kisses Cicero's hands while Cicero struggles (MacDonald 2005, 48:30). Similar episodes of sexualized violence and domination occur between Antony and Cicero throughout the series, as well as between Cicero and Octavian. 
Detective fiction is what some of its disparagers say it is: conservative, almost compulsive in its belief that one may, in truth, trace cause and effect, may place responsibility just here, may pass judgement, may even assess blame, and in its determination not to let us forget that there is evil in the world and that men and women, individual men and women, do it. ${ }^{66}$

Thanks to the Philippicae, Cicero's legacy is dominated by his own decision to turn his prodigious literary talents toward invective, in a passionate attempt to convince the people of Rome that there was evil in their city, and men like Antony were responsible for creating that evil. Though HBO's Rome validates Cicero's decision to attack Antony through their depiction of Antony as increasingly cruel and vindictive, not all portrayals of these events see Cicero's Philippicae as part of a project toward moral justice. For example, the song Crack-Up by the American rock band the Fleet Foxes references the Philippicae in a largely negative light, with the verse:

When the world insists that the false is so With a Philippic, as Cicero. ${ }^{67}$

\section{Conclusions: Killing Cicero}

If we read the fictionalized end of Cicero's life as we would a mystery, the point at which Cicero's own actions will inevitably lead to his death becomes the narrative climax, that classical murder mystery sequence, the revelation of the truth. At what point in the story does any given fictive Cicero discover that, thanks to the Philippics, he has signed his own name on the proscription lists? Some narrative formats forbid their Cicero this revelation in various ways: HBO's Rome insistently characterizes their Cicero as a symbol of what Eran Almagor calls "the clash of rhetorical art and harsh reality" ${ }^{\prime 8}$ rather than a fully developed character in his own right. During the scene in which Cicero is killed in HBO's drama, the thematic focus is drawn to the brutality of the act as a contrast to Cicero's lofty legacy - "I will be in all the history books" Cicero declares - implying the historiographic afterlife of Cicero the historical figure, but leaving Cicero the individual with no time for introspection or regret. ${ }^{69}$ In both Robert Harris'

66 Winks 1980, 10.

67 Pecknold 2017.

68 Almagor 2015, 62.

69 Mahoney 2007, 18:30. 
third Cicero novel, Dictator, ${ }^{70}$ and Mike Poulton's subsequent stage adaptation Imperium, ${ }^{71}$ Cicero's death is filtered through the experiences of a narrator - Cicero's freedman secretary, Tiro. In these works, it is Tiro's reluctant acceptance of Cicero's choices that is the resolution to the mystery, not Cicero's own moral or philosophical understanding of his imminent death.

It is possible that the resounding popular silence around Cicero's own experience of his death is not an accident but rather a feature of Cicero's legacy. We can see a parallel here with how post-classical writers have conceptualized and framed the death of Cicero's beloved daughter Tullia. As Shane Butler explains in his elegant article, “Cicero's Grief”, the text that Cicero wrote to comfort himself after his daughter's death, the Consolatio, has become a meta-symbol of destruction: "Loss, has, itself, been absorbed into and embodied by the very acts of [textual] transmission and reception". ${ }^{72}$ The same loss of life - and the subsequent loss of Cicero's voice in the Roman court, the loss of Cicero's political perspective in the Roman government - may explain the absence of clear moral contemplation in these last moments of any given fictional Cicero. These last thoughts are lost to us, forever an unfinished mystery.

Whether Cicero is portrayed as the morally corrupt defender of a guilty client or as the brilliant Sherlockian detective searching for the truth amidst the chaos of late republican Rome, the fusion of detective tropes with popular portrayals of Cicero reveals a tension between Cicero's own competitive and persuasive priorities and our modern valorization of truth and virtue in our legal heroes. By unpacking the language of mystery that has pervaded Cicero's popular image in recent years, we uncover a desire to find concrete reasons for the fall of the Roman republic. In works that critique Cicero's ethical character, Cicero himself becomes a figure to blame, a symbol for the worst parts of the dying republican regime; in many works that sympathize with Cicero's moral program, however, he becomes the over-idealistic vox populi, crushed under the heel of imminent empire.

Tab. 1: Modern Portrayals of Cicero's Oratory by Date of Ciceronian Speech.

\begin{tabular}{llll}
\hline Cicero Speech Presented (Year) & Name of Work & Author (Year) & Medium \\
\hline Pro Roscio Amerino (80 BCE) & Roman Blood & Saylor & Novel \\
& & $(1991)$ &
\end{tabular}

70 Harris 2015.

71 Poulton 2017.

72 Butler 2018, 14. 
Tab. 1: Modern Portrayals of Cicero's Oratory by Date of Ciceronian Speech. (Continued)

\begin{tabular}{|c|c|c|c|}
\hline Cicero Speech Presented (Year) & Name of Work & Author (Year) & Medium \\
\hline & Murder in Rome, BBC's Timewatch & $\begin{array}{l}\text { Swash } \\
(2005)\end{array}$ & Docudrama \\
\hline & Big Finish's Cicero (Episode I) & $\begin{array}{l}\text { Llewellyn } \\
\text { (2017) }\end{array}$ & $\begin{array}{l}\text { Audio- } \\
\text { drama }\end{array}$ \\
\hline & Il diritto dei lupi & $\begin{array}{l}\text { De Bellis/ } \\
\text { Fiorillo } \\
(2021)\end{array}$ & Novel \\
\hline $\begin{array}{l}\text { Pro muliere Aretina (unknown } \\
\text { date, cf. Pro Caecina } \S 97 \text { ) }\end{array}$ & Big Finish's Cicero (Episodes II-VI) & $\begin{array}{l}\text { Llewellyn } \\
(2018 a)\end{array}$ & $\begin{array}{l}\text { Audio- } \\
\text { drama }\end{array}$ \\
\hline \multirow[t]{4}{*}{ In Verrem (70 BCE) } & A Pillar of Iron & $\begin{array}{l}\text { Caldwell } \\
(1965)\end{array}$ & Novel \\
\hline & Song for Cleomenes & $\begin{array}{l}\text { Darnielle } \\
\text { (1994) }\end{array}$ & Song \\
\hline & Imperium & Harris (2006) & Novel \\
\hline & RSC's Imperium: The Cicero Plays & $\begin{array}{l}\text { Poulton } \\
\text { (2017) }\end{array}$ & Play \\
\hline \multirow[t]{2}{*}{ Pro Fonteio (69 BCE) } & A Pillar of Iron & $\begin{array}{l}\text { Caldwell } \\
(1965)\end{array}$ & Novel \\
\hline & Imperium & Harris (2006) & Novel \\
\hline Pro Cluentio (66 BCE) & The Gift of Rome & $\begin{array}{l}\text { Wagner/ } \\
\text { Wagner } \\
(1961)\end{array}$ & Novel \\
\hline \multirow[t]{6}{*}{ In Catilinam (63 BCE) } & A Pillar of Iron & $\begin{array}{l}\text { Caldwell } \\
(1965)\end{array}$ & Novel \\
\hline & The Catilinarian Conspiracy & $\begin{array}{l}\text { Roberts } \\
\text { (1991) }\end{array}$ & Novel \\
\hline & Catilina's Riddle & $\begin{array}{l}\text { Saylor } \\
(1993)\end{array}$ & Novel \\
\hline & Lustrum & Harris (2009) & Novel \\
\hline & RSC's Imperium: The Cicero Plays & $\begin{array}{l}\text { Poulton } \\
\text { (2017) }\end{array}$ & Play \\
\hline & Big Finish's Tartarus & $\begin{array}{l}\text { Llewellyn } \\
\text { (2019) }\end{array}$ & $\begin{array}{l}\text { Audio- } \\
\text { drama }\end{array}$ \\
\hline
\end{tabular}


Tab. 1: Modern Portrayals of Cicero's Oratory by Date of Ciceronian Speech. (Continued)

\begin{tabular}{|c|c|c|c|}
\hline Cicero Speech Presented (Year) & Name of Work & Author (Year) & Medium \\
\hline Pro Antonio (59 BCE) & $\begin{array}{l}\text { Big Finish's Cicero: The Cross- } \\
\text { roads }\end{array}$ & $\begin{array}{l}\text { Llewellyn } \\
\text { (2021) }\end{array}$ & $\begin{array}{l}\text { Audio- } \\
\text { drama }\end{array}$ \\
\hline Pro Caelio (56 BCE) & The Venus Throw & $\begin{array}{l}\text { Saylor } \\
(1995)\end{array}$ & Novel \\
\hline \multirow[t]{2}{*}{ Pro Milone (52 BCE) } & Death on the Appian Way & $\begin{array}{l}\text { Benton } \\
\text { (1974) }\end{array}$ & Novel \\
\hline & A Murder on the Appian Way & $\begin{array}{l}\text { Saylor } \\
(1996)\end{array}$ & Novel \\
\hline \multirow[t]{5}{*}{ Philippicae (44-43 BCE) } & A Pillar of Iron & $\begin{array}{l}\text { Caldwell } \\
\text { (1965) }\end{array}$ & Novel \\
\hline & $\begin{array}{l}\text { These Being the Words of Marcus } \\
\text { Tullius Cicero, HBO's Rome }\end{array}$ & Buck (2007) & TV show \\
\hline & Dictator & Harris (2015) & Novel \\
\hline & RSC's Imperium: The Cicero Plays & $\begin{array}{l}\text { Poulton } \\
\text { (2017) }\end{array}$ & Play \\
\hline & Crack-Up & $\begin{array}{l}\text { Pecknold } \\
\text { (2017) }\end{array}$ & Song \\
\hline
\end{tabular}

Tab. 2: Modern Portrayals of Cicero's Oratory by Date of Modern Media Publication.

\begin{tabular}{llll}
\hline $\begin{array}{l}\text { Author } \\
\text { (Year) }\end{array}$ & Name of Work & Medium & Cicero Speeches Presented (Year) \\
\hline $\begin{array}{l}\text { Wagner/ } \\
\text { Wagner } \\
(1961)\end{array}$ & The Gift of Rome & Novel & Pro Cluentio (66 BCE) \\
\hline $\begin{array}{l}\text { Caldwell } \\
(1965)\end{array}$ & A Pillar of Iron & Novel & $\begin{array}{l}\text { In Verrem (70 BCE), Pro Fonteio (69 } \\
\text { BCE), In Catilinam (63 BCE), Philippi- } \\
\text { cae (44-43 BCE) }\end{array}$ \\
\hline $\begin{array}{l}\text { Benton } \\
(1974)\end{array}$ & Death on the Appian Way & Novel & Pro Milone (52 BCE) \\
\hline $\begin{array}{l}\text { Roberts } \\
(1991)\end{array}$ & The Catilinarian Conspiracy & Novel & In Catilinam (63 BCE)
\end{tabular}


Tab. 2: Modern Portrayals of Cicero's Oratory by Date of Modern Media Publication. (Continued)

\begin{tabular}{llll}
\hline $\begin{array}{l}\text { Author } \\
\text { (Year) }\end{array}$ & Name of Work & Medium & Cicero Speeches Presented (Year) \\
\hline $\begin{array}{l}\text { Saylor } \\
(1991)\end{array}$ & Roman Blood & Novel & Pro Roscio Amerino (80 BCE) \\
\hline $\begin{array}{l}\text { Saylor } \\
(1993)\end{array}$ & Catilina's Riddle & Novel & In Catilinam (63 BCE) \\
\hline $\begin{array}{l}\text { Darnielle } \\
(1994)\end{array}$ & Song for Cleomenes & Song & In Verrem (70 BCE) \\
\hline $\begin{array}{l}\text { Saylor } \\
(1995)\end{array}$ & The Venus Throw & Novel & Pro Caelio (56 BCE) \\
\hline
\end{tabular}

\begin{tabular}{|c|c|c|c|}
\hline $\begin{array}{l}\text { Saylor } \\
(1996)\end{array}$ & A Murder on the Appian Way & Novel & Pro Milone (52 BCE) \\
\hline $\begin{array}{l}\text { Swash } \\
(2005)\end{array}$ & $\begin{array}{l}\text { Murder in Rome, BBC's } \\
\text { Timewatch }\end{array}$ & Docudrama & Pro Roscio Amerino (80 BCE) \\
\hline $\begin{array}{l}\text { Harris } \\
(2006)\end{array}$ & Imperium & Novel & $\begin{array}{l}\text { In Verrem (70 BCE), Pro Fonteio (69 } \\
\mathrm{BCE})\end{array}$ \\
\hline $\begin{array}{l}\text { Buck } \\
(2007)\end{array}$ & $\begin{array}{l}\text { These Being the Words of } \\
\text { Marcus Tullius Cicero, HBO's } \\
\text { Rome }\end{array}$ & TV show & Philippicae (44-43 BCE) \\
\hline $\begin{array}{l}\text { Harris } \\
(2009)\end{array}$ & Lustrum & Novel & In Catilinam (63 BCE) \\
\hline $\begin{array}{l}\text { Harris } \\
(2015)\end{array}$ & Dictator & Novel & Philippicae (44-43 BCE) \\
\hline $\begin{array}{l}\text { Llewellyn } \\
\text { (2017) }\end{array}$ & Big Finish's Cicero (Episode I) & $\begin{array}{l}\text { Audio- } \\
\text { drama }\end{array}$ & Pro Roscio Amerino (80 BCE) \\
\hline $\begin{array}{l}\text { Pecknold } \\
\text { (2017) }\end{array}$ & Crack-Up & Song & Philippicae (44-43 BCE) \\
\hline $\begin{array}{l}\text { Poulton } \\
\text { (2017) }\end{array}$ & $\begin{array}{l}\text { RSC's Imperium: The Cicero } \\
\text { Plays }\end{array}$ & Play & $\begin{array}{l}\text { In Verrem (70 BCE), In Catilinam (63 } \\
\text { BCE), Philippicae ( } 44-43 \text { BCE) }\end{array}$ \\
\hline $\begin{array}{l}\text { Llewellyn } \\
\text { (2018a) }\end{array}$ & $\begin{array}{l}\text { Big Finish's Cicero (Episodes } \\
I I-V I)\end{array}$ & $\begin{array}{l}\text { Audio- } \\
\text { drama }\end{array}$ & $\begin{array}{l}\text { Pro muliere Aretina (unknown date, cf. } \\
\text { Pro Caecina § 97) }\end{array}$ \\
\hline $\begin{array}{l}\text { Llewellyn } \\
\text { (2019) }\end{array}$ & Big Finish's Tartarus & $\begin{array}{l}\text { Audio- } \\
\text { drama }\end{array}$ & In Catilinam (63 BCE) \\
\hline $\begin{array}{l}\text { De Bellis/ } \\
\text { Fiorillo } \\
(2021)\end{array}$ & Il diritto dei lupi & Novel & Pro Roscio Amerino (80 BCE) \\
\hline
\end{tabular}


Tab. 2: Modern Portrayals of Cicero's Oratory by Date of Modern Media Publication. (Continued)

\begin{tabular}{|c|c|c|c|}
\hline $\begin{array}{l}\text { Author } \\
\text { (Year) }\end{array}$ & Name of Work & Medium & Cicero Speeches Presented (Year) \\
\hline $\begin{array}{l}\text { Llewellyn } \\
\text { (2021) }\end{array}$ & $\begin{array}{l}\text { Big Finish's Cicero: The } \\
\text { Crossroads }\end{array}$ & $\begin{array}{l}\text { Audio- } \\
\text { drama }\end{array}$ & Pro Antonio (59 BCE) \\
\hline
\end{tabular}

